\title{
Workers' Protection in the Covid-19 Era in Nigeria
}

\author{
Ogbole Ogancha $\mathrm{O}^{*}$, Oreoluwa Omotayo Oduniyi ${ }^{* *}$ \\ DOI: https://doi.org/10.22304/pjih.v8n2.a7
}

Submitted: May 30, 2021 | Accepted: August 19, 2021

\begin{abstract}
Against the backdrop of measures adopted sequel to the outbreak of the pandemic, this research focuses on the impact of Covid-19 on the workplace. It highlights and interrogates the utility of responsive measures and also articulates recondite labour issues relating to changing work patterns, pay cuts, job losses culminating in growing unemployment rate, and occupational safety and health concerns within the context of extant labour standards. It also extends focus to the impact of Covid-19 on existing challenges revolving around working poverty, decent work deficit, unfair labour practices, and ineffective labour regimes. This research finds, inter alia, that impact of the Covid-19 pandemic on the workplace is colossal, disruptive, and unprecedented, and that extant labour standards, having proved mute on a wide range of contingent workplace issues, can only provide some sort of protection in a detached manner. The research concludes with an array of farreaching recommendations on the adoption of protective and remedial legal norms that are transient, flexible, and proactive enough to accommodate diverse situations capable of undermining the prospects for labour laws, regulations, and policies in the Covid-19 era.
\end{abstract}

Keywords: covid-19, employment, workplace.

\section{Perlindungan Pekerja pada Masa Covid-19 di Nigeria}

\begin{abstract}
Abstrak
Sehubungan dengan merebaknya pandemi Covid-19, penelitian ini berusaha untuk menjelaskan pengaruh Covid-19 di lingkungan kerja. Penelitian ini menyoroti kebijakan yang dikeluarkan untuk penanganan krisis, serta menggambarkan mengenai permasalahan ketenagakerjaan yang berkaitan dengan perubahan pola kerja, pemotongan gaji, pemutusan hubungan kerja yang menyebabkan tingginya tingkat pengangguran dan kaitannya dengan keselamatan dan kesehatan para pekerja. Lebih jauh lagi, artikel ini juga meneliti dampak Covid-19 di tempat kerja sangat signifikan, dimana hal ini memperparah permasalahan kemisikinan, minimnya pekerjaan yang layak, praktik perburuhan yang tidak adil, dan inefektivitas sistem kerja. Berdasarkan hal tersebut, penulis menyimpulkan bahwa dampak pandemi Covid-19 di tempat kerja sangat besar dan disruptif yang menyebabkan
\end{abstract}

\section{PADJADJARAN Journal of Law Vol. 8 Number 2 Year 2021 [ISSN 2460-1543] [ISSN 2442-9325]}

* Legal Practitioner/Doctoral Research Candidate, Department of Commercial Law, Faculty of Law, University of Jos, Plateau State, Nigeria, LL.M (Ife), BL, ACIS. (University of Jos), ogareuben@yahoo.com.

** Legal Practitioner/Lecturer, Department of Public Law, Faculty of Law, Obafemi Awolowo University, Ile-Ife, Osun State, Nigeria, LL.M (Ife); BL, ACl.Arb (UK), (Obafemi Awolowo University), oreoduniyi@oauife.edu.ng. 
memperburuk masalah ketenagakerjaan. Adapun untuk mewujudkan proteksi kepada para pekerja saat pandemi, penelitian ini merekomendasikan lahirnya norma hukum yang fleksibel dan proaktif guna bisa mengakomodir keberagaman kebutuhan dan memperbaiki kekurangan undang-undang serta kebijakan mengenai ketenagakerjaan di masa Covid-19.

Kata Kunci: covid-19, pekerjaan, tempat kerja.

\section{A. Introduction}

COVID-19 is a global crisis with widespread distortions. ${ }^{1}$ Although COVID-19 originates from the world's manufacturing heartland of China, it has spread fast to the rest of the world. ${ }^{2}$ As a public health emergency of international concern, ${ }^{3}$ the pandemic jiggles arrays of global ideas and subject's global public health response and preparedness to uncommon test. For a number of reasons, the impact of the COVID-19 pandemic on the workplace cannot be ignored. First, unlike previous outbreaks, the disruptive impact of the COVID-19 pandemic on the workplace is colossal and unprecedented. Prior to the outbreak of the pandemic, there exists a lack of qualitative jobs by those gainfully employed. ${ }^{4}$ Workers, especially in rural areas, oftentimes are engaged in less qualitative jobs in a bid to make ends meet. ${ }^{5}$ Such employment tends to be informal, offering low and insecure pay and limited access to social protection and rights at work. ${ }^{6}$ Second, countries across the globe explored all sorts of measures to curb the spread and cushion the impact of the pandemic. ${ }^{7}$ Without prejudice to the experimentation of extant legal norms on

1 The first case of COVID-19 in Nigeria was reported on the $27^{\text {th }}$ of February 2020 and afterwards there has been a steady increase in the numbers of confirmed cases. COVID-19 is the abbreviate for Corona Virus Disease.

2 As of early March 2020, the COVID-19 epidemic was very much centred in China, with over $90 \%$ of reported cases located there. Richard Baldwin and Beatrice Weder di Mauro, Introduction in Richard Baldwin and Beatrice Weder di Mauro, Economics in the Time of COVID-19, United Kingdom: Centre for Economic Policy Research, 2020, p. 14.

3 On $30^{\text {th }}$ January 2020, the World Health Organization declared COVID-19 as a public health emergency of international concern. On $11^{\text {th }}$ March 2020, the World Health Organisation (WHO) declared COVID-19 as a pandemic. As of $13^{\text {th }}$ May 2020, all African country had recorded case(s) of COVID-19, the last being Lesotho.

4 International Labour Organisation, "World Employment and Social Outlook: Trends 2020", https://www.ilo.org/wcmsp5/groups/public/---dgreports/---dcomm/--publ/documents/publication/wcms_734455.pdf, accessed on May 2021. Ibid.

Ibid.

7 On 30 $30^{\text {th }}$ March 2020, Nigerian President made the COVID-19 Regulations 2020. Under paragraphs 1 and 3 COVID-19 Regulations 2020, the President imposed restriction/cessation of movement in Lagos State, Ogun State and Federal Capital Territory, Abuja, and suspended commercial aircraft (private and commercial). Similarly, on $17^{\text {th }}$ March 2020, Colombian's President, declared the state of economic, social and ecological emergency through the Decree 457 of 2020. This Declaration allows the government to issue the necessary decisions to address challenges posed by COVID-19. On this basis, among other measures, Colombia closed its land, sea and river borders from the $17^{\text {th }}$ March 2020 to 30 th May 2020. See also, Juan Pablo López Moreno, Luz Angela Duarte González and Juliana Morad, "COVID-19 and Labour Law: Colombia", Italian Labour eJournal, Vol. 13, No. 1S, 2020, pp. 1-2. 
workers' protection against the backdrop of the resulting changing work patterns, pay-cuts, job-losses culminating in the growing unemployment rate and workplace health concerns which are as a result of the pandemic, making the workplace most affected. This is particularly so for emerging labour markets that are intrinsically characterized by working poverty, ${ }^{8}$ decent work deficits, ${ }^{9}$ and unfair labour practices. ${ }^{10} \mathrm{It}$ is, therefore, expedient to tinker with extant normative precepts on workers' protection against the backdrop of the array of challenges posed by the COVID-19 pandemic.

COVID-19 is an infectious viral disease caused by strains of coronavirus. The disease was first discovered in December 2019 in the city of Wuhan in China, from where it spread to virtually all countries across the globe. As a disease with links to the Severe Acute Respiratory Syndrome (SARS), COVID-19 is mainly transmitted through droplets generated by infected persons, mainly through coughing, sneezing, and touching of contaminated surfaces. Those infected with COVID-19 experience mild to moderate symptoms and sometimes recover without special treatment. ${ }^{11}$ Notwithstanding the fact that the global understanding of the severity, clinical features, and prognostic factors of COVID-19 remains incomplete, key preventive measures include the use of personal protective equipment, frequent washing of hands with soap and water or the use of alcohol-based sanitiser, respiratory hygiene in the nature of covering of mouth and nose with flexed elbow or tissue when coughing or sneezing, self-isolation, social distancing, and avoidance of close contact with anyone with cold or flu-like symptoms. Compared to previous pandemic outbreaks such as the Asian Influenza, Avian Flu, Severe Acute Respiratory Syndrome (SARS), Middle East Respiratory Syndrome (MERS) and Ebola Virus Disease (EVD), human-to-human transmission of COVID-19

$8 \quad$ The concept of "working poverty" was developed by the International Labour Organisation (ILO) refers to situation where poverty ravages low-income workers who are trapped by poverty though gainfully employed. The category of workers affected by working poverty (i.e., working poor) usually have incomes that fall below a given poverty line or threshold due to lack of work hours and/or low wages. Working poverty may assume the nature of extreme poverty. In International Labour Organisation, op.cit., p. 20.

9 Goal 8 of the Sustainable Development Goals (SDGs) adopted in 2015 by member states of the United Nations represents a global mandate to advocate a befitting work environment. The totality of the desire of workers is to have access to jobs Decent that provide fair income, acceptable terms and conditions, equal treatment, social protection opportunities and vagaries of rights at work. In other words, decent work relates directly to the quality of employment which reflects in the extent in which workers are able to circumvents poor-quality employment evidenced by working poverty.

10 Tayo Fashoyin, Industrial Relations in Nigeria: Development and Practice, Nigeria: Learn Africa Plc, 1992, p. 11.

11 The symptoms of COVID-19 include fever, dry cough, sore throat, headache, tiredness, nasal congestion, conjunctivitis, sore throat, diarrhoea, loss of taste or smell, skin rashes, discoloration of fingers or toes, and shortness of breath. In severe cases, the disease can cause pneumonia (breathing difficulties), pulmonary failure and ultimately death. The symptoms may take up to fourteen days to appear after exposure to the disease, and the disease can be transmitted by both carriers that have not yet developed symptoms (presymptomatic) and those that never develop symptoms (asymptomatic). 
is rapid. ${ }^{12}$ Much earlier, when vaccines were being developed with some at the stage of clinical trials, ${ }^{13}$ recourse was had to Lopinavir, Ritonavir, Chloroquine, Hydroxychloroquine, Organic/Herbal Remedies. ${ }^{14}$

\section{B. Corona Virus and the Workplace}

Unlike previous pandemics, ${ }^{15}$ the Coronavirus has had an intense effect on the workplace. It has triggered a proliferation of flexible work arrangements outside the precinct of standard or conventional work arrangements. These flexible work arrangements include home-based work, piece-rate work, part-time work, telework and so on. Employers of labour whose activities can be done remotely had told their workers to work from home before the stay-at-home directive of the government. ${ }^{16}$ Other employers whose businesses could not be effectively conducted remotely had to temporarily shut down and their workers were told to stay home with either full pay or reduced salaries or placed on temporary layoffs without pay. ${ }^{17}$ Some employees lost their jobs in extreme cases. ${ }^{18}$ In spite of the loss of jobs occasioned by the resulting termination of employment, the unprecedented global demand for personal protective equipment as well as diagnostics and clinical care products is a booster for the workplace and workers engaged in the production of these items.

Regarding home-based work, which is gaining prominence, workers in telecommunication companies, broadcasters, print, and electronic media who can prove they are unable to work from home are exempted from the restriction/cessation of movement in Lagos State, Ogun State, and the Federal Capital Territory, Abuja, Nigeria. ${ }^{19}$ Physical meetings and engagements mostly became online and virtual. This change is profound in that it alters the traditional understanding of what constitutes work at both the global and domestic labour

12 By $7^{\text {th }}$ September 2020, there were 26,994,442 confirmed cases of COVID-19, including 880,994 deaths. See World Health Organization, "WHO Coronavirus Disease (COVID-19) Dashboard", https://covid19.who.int/, accessed on September 2020.

13 University of Oxford, "Oxford COVID-19 Vaccine to Begin Phase II/III Human Trials", http://www.ox.ac.uk/news/2020-05-22-oxford-covid-19-vaccine-begin-phase-iiii-human-trials, accessed on May 2020.

14 In Africa, Madagascar is the first country to launch and make public organic cure for Covid 19. The remedy was developed by the Malagasy Institute of Applied Research and branded "COVID Organics."

15 The $21^{\text {st }}$ century has witnessed four other pandemic outbreaks: N1H1 (Bird Flu) in 2009, Severe Acute Respiratory Syndrome (SARS) in 2002, Middle East Respiratory Syndrome (MERS) in 2012, and Ebola which peaked in 2013-2014. See R. Baldwin and Weder di Mauro, op.cit., p. 5.

16 Philip Osarobo Odiase, "COVID-19 and Labour Law: Nigeria", Italian Labour Law e-Journal, Vol. 13, No. 1S, 2020, p. 13.

17 Ibid.

18 Ibid.

19 Covid-19 Emergency Regulations 2020, paragraph 1(10). 
markets. In other words, the emerging work arrangements are detached, deepseated and distortive of the pre-COVID-19 notion of the workplace.

At the international echelon, enterprises have witnessed disruption in services, productions and supply chain as a result of a collapse in demand. In some instances, operations have had to be suspended or scaled down. For enterprises that are not resilient enough, closure becomes inevitable. By the first quarter of 2020, it was reported that working hours had declined by an estimated 4.5 percent globally. ${ }^{20}$ This continued sharp decline in working hours has had an adverse effect on an estimated 1.6 billion workers in the informal economy, which poses a great danger to the means of livelihood of workers. ${ }^{21}$ The pandemic has also caused a reduction in the working hours in the informal sector, which has led to a loss of income with little possibility of receiving employment benefits. ${ }^{22}$ The unexpected extension of the lockdown and other restrictive measures has also caused a widespread reduction in working hours. Existing inequalities in relation to income have also been exacerbated by the pandemic. The strain on incomes resulting from the decline in economic activities has significantly increased working poverty.

In Nigeria, the domestic labour market has had to contend with challenges arising from the imposition of lockdowns, curfews, border closures, self-isolation, quarantine and social distancing measures, contact tracing, travel bans and restrictions. ${ }^{23}$ These measures are in response to the invocation of the provisions of the Quarantine Act, 1926, ${ }^{24}$ as well as the COVID-19 Emergency Regulations, 2020 made pursuant to the powers derived by the President pursuant to the enabling legislation. ${ }^{25}$ The invocation of provisions of the Quarantine Act, 1926 by the President as a statutory basis for issuance of COVID-19 Emergency Regulations, 2020 is largely hinged on public health protection exigencies. ${ }^{26}$ Under the Quarantine Act, 1926, contravention of any regulations made pursuant to the powers derived from the Quarantine Act, 1926 is liable to a fine of $\$ 200$ or to imprisonment for a term of six months or to both. ${ }^{27}$ The President is empowered to declare, by notice, any infectious or contagious disease as a "dangerous

20 International Labour Organisation, "ILO Monitor: COVID-19 and the World of Work", https://www.ilo.org/global/topics/coronavirus/impacts-and-responses/WCMS_767028/lang--en/index.htm, accessed on May 2021.

21 Workers in the informal sector affected by the pandemic include the self-employed, casual and gig workers who are not protected by conventional social security protection mechanisms. See International Labour Organisation, "ILO: As Job Losses Escalate, Nearly Half of Global Workforce at Risk of Losing Livelihoods", https://www.ilo.org/global/about-the-ilo/newsroom/news/WCMS_743036/lang--en/index.htm, accessed on May 2021.

22 International Labour Organisation, "COVID-19: Protecting Workers in the Workplace", https://www.ilo.org/global/about-the-ilo/newsroom/news/WCMS_740101/lang--en/index.htm, accessed on May 2020.

23 The first case of Covid-19 in Nigeria was recorded on 27 $7^{\text {th }}$ February, 2020.

24 The Quarantine Act 1926 is currently codified as Cap Q2, Laws of the Federation of Nigeria 2004.

25 Ibid, section 4.

26 Ibid, sections 2, 3, and 4.

$27 \quad$ lbid, section 5 . 
infectious disease." ${ }^{28}$ In exercise of this power, COVID-19 was declared by the President on $30^{\text {th }}$ March 2020 as a "dangerous infectious disease" with restriction/cessation of movement in Lagos State, Ogun State and the Federal Capital Territory, Abuja, ${ }^{29}$ and suspended commercial aircraft. ${ }^{30}$ Where this power is not exercised by the President, the Governor of a State is empowered to make such declaration in respect of a State under the same conditions and limitations. ${ }^{31}$

As a nation that is highly reliant on foreign exchange proceeds from sales of crude oil at the international market, the declining performance of the domestic labour market in Nigeria is further aggravated by a sharp fall in the price of oil, low production due to production cuts and the reduced global demand for oil. To protect the nation's fiscal fortunes, the International Monetary Fund had granted Nigeria a \$3.4 Billion Rapid Financing Instrument (RFI) to alleviate the impact of the COVID-19 and the sharp fall in oil prices. ${ }^{32}$ In addition, the Central Bank of Nigeria created the $\$ 50$ Billion Targeted Credit Facility to support affected households, businesses, regulated financial institutions and other stakeholders. It is estimated that 40-70 percent of the entire world could become infected, ${ }^{33}$ these monetary interventions are timely. However, the impact of the interventions on the workplace remained entirely a different matter altogether. More so, the COVID-19 pandemic raises recondite and precarious issues of concerns that cannot be ignored. Therefore, the fundamental question remains whether the labour law model, in its present form, can address these recondite labour issues. To proffer a concrete response, it is expedient to articulate extant labour standards containing specific guidance on these recondite labour issues.

\section{Pay-Cuts as Workplace Austerity Measure}

It is trite that most individuals get their means of livelihood from earnings from their workplace. ${ }^{34}$ Often times low income is characterised by poor working conditions. ${ }^{35}$ As part of broader austerity measures to cushion the impact of the COVID-19 pandemic in the workplace, employers have resorted to pay cuts where

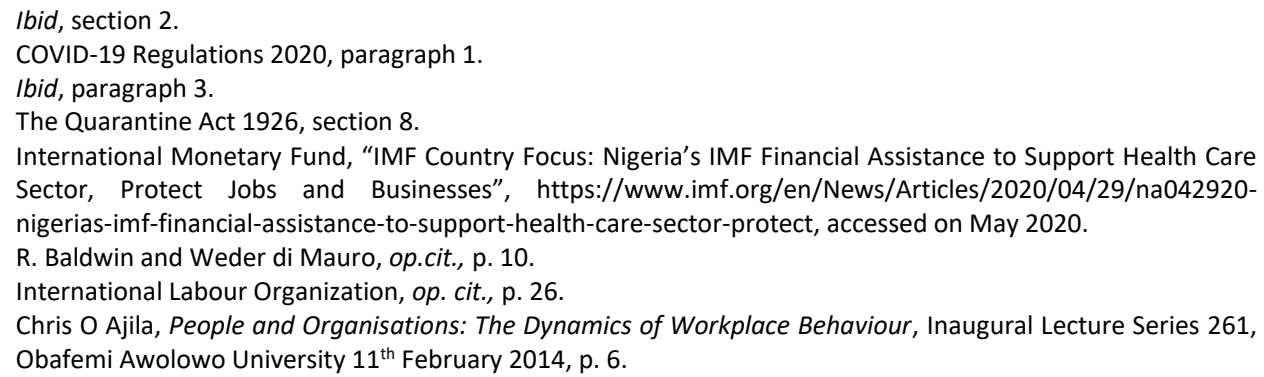


such an option is considered expedient. ${ }^{36}$ Pay-cuts alter the incidence of the major consideration that arises from the contract of employment and undermines incentive and motivation for work. It is also capable of pushing workers into underemployment and working poverty. Earnings from the workplace are expected to be a means of sustenance for workers and their families, pay-cuts are often accompanied by stiff resistance by workers and workers' trade unions, resulting in trade disputes and all sorts of industrial actions. In most cases, pay-cut is a hard but inevitable decision for employers of labour. While pay-cuts may be a valid strategy to keep business afloat, the extent to which it is legally permissible is a different point altogether. Aside from providing for regular payment of wages, employers are prohibited from making deductions out of a worker's or an employee's salary except to the extent prescribed by national laws or regulations or fixed by a collective bargaining agreement or an arbitration award. ${ }^{37}$ Workers must be adequately informed about the rationale for such reduction with detailed terms and conditions by the employer. ${ }^{38}$ This is a clear prohibition of unilateral deduction of wages. In line with these prescriptions lies the question of whether national laws or regulations in Nigeria permit wage deduction.

Under the Labour Act, 2004, employers cannot make any wage deductions or enter into an agreement or contract with a worker regarding wage deductions. ${ }^{39}$ The principle of non-deduction of wages laid down by this provision is further strengthened by section 16 Labour Act, 2004 which provides that an employee be paid sick leave of up to twelve working days in one calendar year where absence from work is caused by a temporary illness certified by a registered medical practitioner. Again, section 18 Labour Act, 2004, guarantees annual holidays with pay under certain parameters. However, the principle of non-deduction of wages as a general rule has a number of exceptions. Some of which are that deduction can be made from the wages of workers with the prior consent in writing of an authorised labour officer. ${ }^{40}$ In this respect, the deduction must be reasonable and in relation to injury or loss caused to the employer by the wilful misconduct or neglect of the worker. ${ }^{41}$ Second, the employer may, with the consent of a worker, make deductions from the wages and pay to the appropriate person any contributions to provident or pension funds or other schemes agreed to by the worker and approved by the State Authority. ${ }^{42}$ Furthermore, deduction of check-off

\footnotetext{
36 In England, Italy and Spain, major football clubs have had to reduce salaries of their players. In Nigeria, Arik Air Limited, an indigenous aviation company, recently announced that it had ordered $90 \%$ of its staff to proceed on leave without pay until further notice, and implemented an $80 \%$ salary cut for the month April, 2020. 
dues can be made on the wages and salaries of workers that are legal members of any of the trade unions for onward remittance to trade union accorded recognition by the employer.$^{43} \mathrm{~A}$ concerned worker must have accepted, in writing, to make such a voluntary contribution. ${ }^{44}$ Also, there could be deductions from the wages where overpayment had occurred three months immediately preceding the month in which the overpayment was discovered..$^{45}$ However, the total amount that can be deducted in a month cannot exceed one-third of the wages of the worker for that month. ${ }^{46}$ These exceptions provide windows for pay-cuts of some sort. While these limits the extent to which pay cuts can be utilised as an austerity measure in the workplace, it is not out of place for workers to accept pay-cuts in lieu of termination of employment. However, whatever pay-cut that may be imposed by the employer or accepted by workers cannot be lower than the threshold imposed by the extant minimum wage regime. ${ }^{47} \mathrm{~A}$ downward review of the workers' remuneration that is less than the minimum wage is void. ${ }^{48}$ This is owing to the fact that minimum wage is intended to guarantee a life outside working poverty. ${ }^{49}$

\section{Impact of Job-Losses on Growing Unemployment Rate}

COVID-19 slowed down economic growth. When this concern is placed side-by-side with the exigencies for the automation of the workplace in the wake of reliance on new technologies and digital labour platforms, a rise in unemployment becomes inevitable..$^{50}$ The workplace has witnessed increased reliance on robots for the performance of boring, unsafe, and undesirable tasks. While this workplace dynamic proved valuable in reducing labour cost and increasing productivity, the fear that machines could mop up jobs traditionally performed by humans creates some level of uncertainty and renders the future of the workplace bleak. This is more so that these robots are increasingly able to execute complex tasks with little or human intervention. Save for emerging work patterns, attention has drifted from job creation to the preservation of existing jobs in the wake of the outbreak of COVID-19. A major legislative effort in this regard is pending before the Nigerian

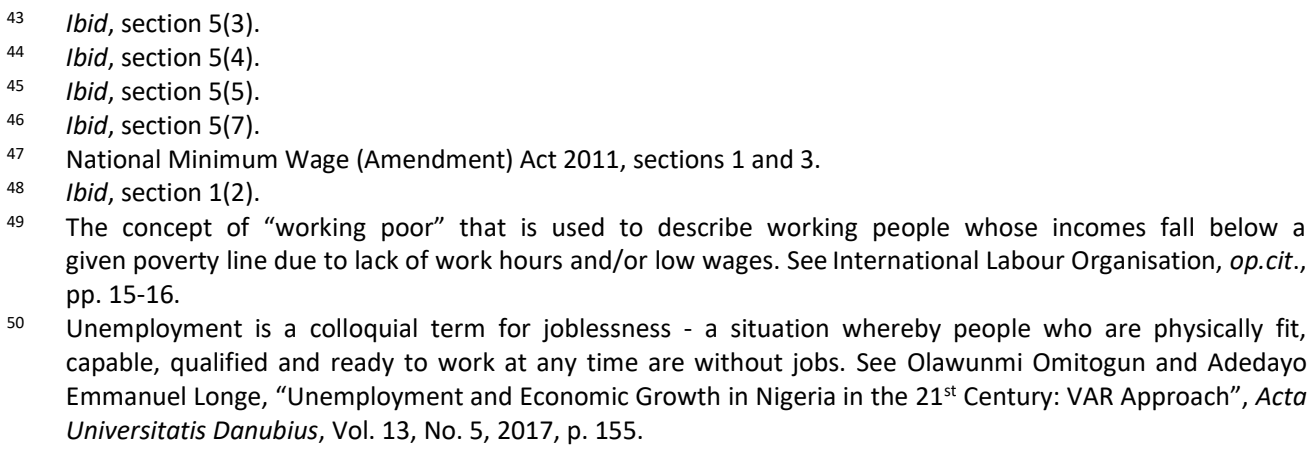
capable, qualified and ready to work at any time are without jobs. See Olawunmi Omitogun and Adedayo Emmanuel Longe, "Unemployment and Economic Growth in Nigeria in the $21^{\text {st }}$ Century: VAR Approach", Acta Universitatis Danubius, Vol. 13, No. 5, 2017, p. 155. 
Senate. It provides, inter alia, for 50 percent tax refund for companies that do not lay off staff between the $31^{\text {st }}$ of March 2020 and $31^{\text {st }}$ of December 2020 (except for reasons related to a breach of Labour Act). ${ }^{51}$ Tuck in this legislative effort is the need to avert unemployment through financial incentives in the nature of tax refunds.

Unemployment affects a segment of the labour force population (employed, underemployed and unemployed), covering all persons aged 15 to 64 years who are willing and able to work regardless of whether they have a job or not. ${ }^{52}$ Nonengagement of an unemployed person must necessarily be coupled with employability/fitness for the task(s) and active search for a job. ${ }^{53}$ Unemployment remains a major labour market performance indicator. ${ }^{54}$ When wrongful termination of employment occurs, the only remedy available to the affected employee is the pre-existing deficient labour law framework. ${ }^{55}$ Sequel to the outbreak of COVID-19, unemployment remains a critical issue. ${ }^{56}$ At the global level, unemployment stood at 190 million prior to the outbreak of COVID-19. ${ }^{57}$ This situation is most critical in North Africa. It has the highest unemployment rate among the sub-regions. ${ }^{58}$ In Nigeria, the unemployment rate increased from 27.1 percent in the second quarter of 2020 to 33.3 percent in the fourth quarter of $2020 .^{59}$ It has been projected by the International Labour Organisation that there would be up to 25 million job losses globally as a result of the COVID-19 pandemic; thus, the shrinking employment space in Nigeria gives credence to this projection. ${ }^{60}$ Individuals who require jobs to survive under the current unemployment rate are inherently disadvantaged and imbued with the most inferior bargaining power. ${ }^{61}$

51 The Bill pending before the Senate is long-titled "A Bill for an Act to Provide for Relief on Corporate Tax Liability, Suspension of Import Duty on Selected Goods and Deferral of Residential Mortgage Obligations to the Federal Mortgage Bank of Nigeria for affixed term to protect jobs and alleviate financial burden on citizens in response to the economic downturn occasioned by the outbreak of COVID-19 disease." The Bill was passed by the House of Representatives on $24^{\text {th }}$ March 2020, and currently pending before the Senate.

52 National Bureau of Statistics, "Labour Force Statistics - Volume I: Unemployment and Underemployment Report (Q4 2017-Q3 2018)", https://nigerianstat.gov.ng/, accessed on September 2020.

53 International Labour Organisation, "Labour Force", https://www.ilo.org/global/statistics-anddatabases/statistics-overview-and-topics/WCMS_470304/lang--en/index.htm, accessed on May 2020.

54 Olawunmi Omitogun and Adedayo Emmanuel Longe, op.cit., p. 156.

55 Philip Osarobo Odiase, op.cit., p. 4.

56 Olawunmi Omitogun and Adedayo Emmanuel Longe, op.cit., p. 156.

57 Cansel Oskay, "Youth Unemployment in the World and in Turkey After the Post Global Financial Crisis Period" in Samet Evci and Anshuman Sharma, Studies at the Crossroads of Management \& Economics, Turkey: Ijopec Publication, 2020, p. 97.

58 International Labour Organisation, op.cit., p. 42.

59 The current unemployment rate translates to 23,187,389 million Nigerians unemployed in the period under review. See National Bureau of Statistics, "Labour Force Statistics: Unemployment and Underemployment Report (Q4 2020)", https://nigerianstat.gov.ng/, accessed on March 2021.

60 The unemployment rate is a useful measure of the underutilization of the labour supply. It reflects the inability of an economy to generate employment for those persons who want to work but are not doing so, even though they are available for employment and actively seeking work. See International Labour Organization, "ILO Standards and COVID-19 (Coronavirus)", https://www.ilo.org/wcmsp5/groups/public/--ed_norm/---normes/documents/publication/wcms_739937.pdf, accessed on May 2020.

61 Dafe Otobo, Industrial Relations: Theory and Controversies, Nigeria: Malthouse Press Limited, 2013, p. 7. 
Job losses remain a traumatic experience for workers since the resulting loss of incomes directly impacts workers' well-being and family life. ${ }^{62}$ Apparently, unemployment on account of COVID-19 creates a crisis within a crisis that requires extraordinary measures to safeguard business continuity.

Under relevant International Instruments, there has to be a cogent reason before a contract of employment can be terminated on the grounds of the employee's conduct or ability or workplace requirement. ${ }^{63}$ Also, ill-health or urgent family concerns are not sufficient grounds for termination of employment. ${ }^{64}$ Grounds associated with employees ability or workplace requirements are considered acceptable. ${ }^{65}$ There must be a legitimate motive for such termination and an affected worker must be afforded the opportunity to defend himself. ${ }^{66}$ The insistence on a legal ground for termination of employment has precluded an employer from laying off workers due to COVID-19 and any other reason. Termination of employment based on economic reasons is not just sufficient, an employer must provide detailed reasons which will include the specific workers who will be affected and time frame. It is trite that before such termination is carried out, the employer must consult with the worker's representative for possible intervention on how to avert same or minimise its effect on concerned workers. ${ }^{67}$ This is without prejudice to the obligation to notify competent authority when such termination is contemplated. ${ }^{68}$ Also, there are competent bodies saddled with the responsibility of ameliorating the adverse effects on the termination of employment by ensuring that all pending issues relating to and arising from it are resolved. ${ }^{69}$ There should be provision for access to job promotion measures, skilled training and employment services for workers who have lost their jobs targeted at reintegrating them back to the workforce. ${ }^{70}$ Due to loss of means of livelihood, It is imperative to have a scheme of compensation aimed at facilitating unemployment benefits or help for workers whose employment is

62 International Labour Organisation, "International Labour Standards on Employment Security", http://www.ilo.ch/global/standards/subjects-covered-by-international-labour-standards/employment-

security/lang--en/index.htm, accessed on May 2020.

63 Termination of Employment Convention 1982 (No. 158), article 4.

64 Ibid, Article 6(1); Workers with Family Responsibilities Convention 1981 (No. 156), Article 8.

65 Ibid.

66 Termination of Employment Convention 1982 (No. 158), article 7.

67 Ibid, Article 13.

68 Ibid, Article 14.

69 Termination of Employment Recommendation 1982 (No. 166), paragraph 19.

70 Employment Promotion and Protection Against Unemployment Convention 1988 (No. 168), articles 7-9 jo. Employment Promotion and Protection against Unemployment Recommendation 1988 (No. 176), paragraph 2. 
suspended, reduced or terminated due to the economic impact of COVID-19 or on the grounds of health and safety. ${ }^{71}$

However, the Labour Act, 2004 failed to compel employers to state reason(s) for termination of employment as against the prescribed rules under international labour standards. ${ }^{72}$ Furthermore, grounds for termination of a contract of employment varies. It can be due to the expiration of the period for which it was made, the death of the worker before the expiry of that period, or by the legally permissible way by a notice with which such contract is terminable. ${ }^{73}$ However, the form of termination that can be inferred from this provision is termination by performance, termination by frustration and termination by notice. ${ }^{74}$ In times past, decisions of the courts revealed that a contract of employment could be terminated on different grounds or none specifically. ${ }^{75}$ It has been stated that once there is compliance with the notice period contained in the contract of employment, the employer need not state the motive for termination. ${ }^{76}$ Employers' unfettered right to "hire and fire" ${ }^{\text {"77 }}$ is in tandem with the position at common law from which a large chunk of extant labour regime is drawn from. ${ }^{78}$ While a willing employee cannot be imposed on an unwilling employer and the employers cannot be mandated to retain an employee, ${ }^{79}$ some recent decisions of the National Industrial Court of Nigeria indicate that termination without valid or justifiable reason(s) connected with capacity or conduct of the employee or based on the operational requirements of the establishment is contrary to international best practices and constitutes an unfair labour practice. ${ }^{80}$ In this regard, an employer contending that a worker's "service is no longer required" is not a valid reason for termination of employment. ${ }^{81}$ In Petroleum and Natural Gas Senior Staff

71 Employment Promotion and Protection Against Unemployment Convention 1988 (No. 168), article 10 jo. Social Security (Minimum Standards) Convention 1952 (No. 102), part IV.

72 Gabriel Ativie v. Kabel Metal Nig. Limited (2008) LCN/3539 (SC).

73 The Labour Act 2004, section 9(7).

74 Chioma Kanu Agomo, Nigerian Employment and Labour Relations: Law and Practice, Nigeria: Concept Publications Limited, 2011, p. 159.

75 Olaniyan v. University of Lagos \& Anor (1985) 2 NWLR (Pt 9) 599, 612; Nigerian Oil Mills Ltd. v. Daura (1996) 8 NWLR (Pt 468) 601; Isievwore v. NEPA (2002) 13 NWLR (Pt 784) 417, 434. See also Elizabeth A. Oji and Offornze D. Amucheazi, Employment \& Labour Law in Nigeria, Nigeria: Lawscope Publishers, 2019, p. 13.

76 Emmanuel OC Obidimma, MI Anushiem and UMJ Ekeneme, "Unfair Dismissal in Nigeria: Imperative for A Departure from The Common Law", Nnamdi Azikiwe University Journal of International Law and Jurisprudence, Vol. 7, 2016, p. 134.

77 SC Srivastava, Industrial Relations and Labour Law, India: Vikas Publishing House PVT Ltd, 2007, p. 327.

78 Oladosu Ogunniyi, Nigerian Labour and Employment Law in Perspective, Nigeria: Folio Publishers Limited, 2004, p. 5. See also Akintunde Emiola, Nigerian Labour Law, Nigeria: Emiola Publishers Limited, 2008, p. 5.

79 Adewunmi v. Nigerian Eagle Flour Mills (2014) LPELR-22557(CA); Savannah Bank Plc v. Fakokum (2002) 1 NWLR (Pt 749) 544; De Franscesco v. Barnum (1890) 45 Ch.D 430, 438. See also Nwagbara, Determination of Contract of Employment and Remedies for Wrongful Dismissal, Nigeria: Tait Publishers, 2000, p. 106.

$80 \quad$ Ebere Onyekachi Aloysius v. Diamond Bank Plc (2015) 58 NLLR (Pt 199) 92.

81 Ibid. 
Association of Nigeria v Schlumberger Anadrill Nigeria Ltd. ${ }^{82}$ the National Industrial Court of Nigeria, per Justice Adejumo, PNICN, observed:

"The respondent also argued that it has the right to terminate the employment of any of its employees for reasons or no reason at all. While we do not have any problem with this at all, the point may be made that globally it is no longer fashionable in industrial relations and practice to terminate an employment without adducing any reason for such a termination." ${ }^{\prime 83}$

This view is a clear indication of a shift from strict common law principles to progressive international labour standards that entrench social justice in the workplace. Assuming without conceding that the job losses in the wake of COVID19 are predicated on redundancy, it remains to be seen if the procedure for redundancy is complied with. First, workers' trade unions have the right to be consulted before any retrenchment can be carried out on account of redundancy. ${ }^{84}$ This underscores the importance of social dialogue as well as the vital role of employers' and workers' organisations in responding to crisis situations. ${ }^{85}$ Second, the principle of "last in, first out" must be observed in determining the workers or categories of workers to be made redundant. ${ }^{86}$ This is, however, subject to factors relating to relative merit (including skill, ability, and reliability). ${ }^{87}$ Non-compliance with this provision amounts to unfair labour practice, which may entitle workers affected to damages. ${ }^{88}$ Third, mandatory redundancy payments must be paid to the redundant workforce. ${ }^{89}$ Beyond these considerations, whether the loss of jobs on account of COVID-19 squarely fits into the precinct of the statutory construction of redundancy remains quite arguable.

Redundancy is defined as an involuntary and permanent loss of employment caused by the excess of manpower. ${ }^{90}$ The expression "involuntary and permanent loss of employment" clearly makes the loss of job on account of redundancy

82 Petroleum and Natural Gas Senior Staff Association of Nigeria v. Schlumberger Anadrill Nigeria Ltd. (2008) 11 NLLR (Pt 29) 164.

83 Ibid.

84 The Labour Act, 2004, section 20(1)(a).

85 Employment and Decent Work for Peace and Resilience Recommendation, 2017 (No. 205), paragraph 7(k), 24 and 25. The obligation to consult workers' trade unions on an anticipated redundancy also takes into account pre-existing international labour standards, such as the Freedom of Association and Protection of the Right to Organise Convention 1948 (No. 87) and the Right to Organise and Collective Bargaining Convention 1949 (No. 98) which seek to keep workers and their trade unions informed and consulted on measures to be taken by employers in times of heightened social tension in the workplace.

86 The Labour Act, 2004, section 20(1)(b).

87 lbid.

88 Food, Beverage \& Tobacco SSA v. Premier Breweries (1989-90) NICLR 56.

89 The Labour Act, 2004, section 20(1)(c).

90 Ibid, section 20(3). 
unintended and without remediation, complicity and causative involvement of both the employers and employees. In other words, "a redundancy occurs when the services of a worker, having been in the continuous employment of an employer, are no longer required by that employer due to no fault of the worker." 91 The occurrence of a temporary emergency or other situations beyond the control of the employer is contemplated under the law. ${ }^{92}$ However, the period of such exigencies is usually not more than a week or more than where it is authorized by a labour officer in peculiar circumstances. ${ }^{93}$ Clearly, the COVID-19 pandemic falls outside these prescriptions.

\section{Occupational Safety and Health Considerations}

Prior to the outbreak of the Corona Virus, the health sector of most African Countries was in bad shape. There was a shortage of basic infrastructure and personal protective equipment. Thus, it has been challenging to tackle the health care problems posed by the COVID-19 pandemic, particularly for healthcare workers who have tested positive for COVID-19.94 Among frontline workers, workers engaged in healthcare services are most vulnerable to COVID-19. ${ }^{95}$ Globally, there are 3.3 billion workers. ${ }^{96}$ Out of which 2 billion are engaged in jobs in the informal economy. ${ }^{97}$ There appears to be no concrete protection measure for the self-employed, casual workers, and employees in the informal economy. ${ }^{98}$ This shows that having a job is no guarantee for decent work. ${ }^{99}$ As a core aspect of decent work, the importance of occupational safety and health was recognised in the 2030 Agenda for Sustainable Development which seeks the protection of labour rights and the promotion of safe and secure working environments for all workers, including migrant workers and those in precarious employment. ${ }^{100}$ The outbreak of COVID-19 resuscitates a wide spectrum of issues relating to occupational safety and health. ${ }^{101}$ Issues relating to mental health and stress for healthcare providers are on the increase, asides from the risk of direct infection from patients and co-

\footnotetext{
91 Union of Shipping, Clearing and Forwarding Agencies Workers of Nigeria v. Management of Transatlantic Nigeria Limited (1988) Unreported Suit No. NIC/14/87.

92 The Labour Act 2004, section 17(1)(a).

93 Ibid.

$94 \quad$ Phillip Osarobo Odiase, op.cit., pp. 2-3.

95 Will Oliver, "Healthcare Workers and Coronavirus: Behind the Stiff Upper Lip We Are Highly Vulnerable", https://theconversation.com/healthcare-workers-and-coronavirus-behind-the-stiff-upper-lip-we-are-highlyvulnerable-133864, accessed on May 2020.

96 United Nations, "Nearly Half of Global Workforce at Risk as Job Losses Increase Due to COVID-19: UN Labour Agency", https://news.un.org/en/story/2020/04/1062792, accessed on May 2020.

97 Ibid.

$98 \quad$ Phillip Osarobo Odiase, op.cit., p. 4.

99 Decent work is productive work which provides workers with adequate earnings, ensuring satisfactory living conditions for workers and their families.

100 Target 8.8 of 2030 Agenda for Sustainable Development.

101 The theme of the 2020 World Day for Safety and Health at Work is "Stop the pandemic: Safety and Health at Work Can Save Lives."
} 
workers during the COVID-19 pandemic as it occurred during the outbreak of the SARS epidemic. ${ }^{102}$ Though there is intense pressure on the healthcare workforce globally, reports show that there is already a shortage of health workers. ${ }^{103}$ This is occasioned by the apparent workload on the existing health workforce, the accompanying health and safety risks, as well as low pay. It has hindered many from working in the health sector, while many qualified health workers have left the profession prematurely. ${ }^{104}$ Though governments have the mandate to review existing health and safety regulations, particularly those relating to occupational health and safety, noting the peculiar nature of the health sector, ${ }^{105}$ there are other normative prescriptions under international and domestic labour standards that offer some sort of protection for health workers and other frontline workers.

Under international labour standards, it is the duty of the employer to provide preventive and protective measures in combating occupational risks associated with the workplace. ${ }^{106}$ As such, employers have the duty to provide adequate protective clothing and protective equipment to the worker. ${ }^{107}$ Furthermore, it is the duty of the employer to ensure safety measures exist at the workplace, as well as that of machines, equipment without posing any threat to health. ${ }^{108}$ In addition, the employer has an obligation to provide necessary information and training to improve safety and health at the workplace and consult relevant officials on operational safety and health aspects associated with their work. ${ }^{109}$ The employer has an obligation to provide measures to handle workplace emergencies ${ }^{110}$ and notify the relevant authorities where occupational diseases are contracted. ${ }^{111}$ There should exist detailed workplace measures for workers to report urgent situations that could pose a serious danger to life or health. Where this happens, if necessary, the employer cannot require workers to return to a work situation where there is continuing imminent and serious danger to life or health until the employer has taken necessary remedial action. ${ }^{112}$ The exercise of this right cannot be meted with undue consequences by the employer. ${ }^{113}$

102 Malcolm R Sim, "The COVID-19 Pandemic: Major Risks to Healthcare and Other Workers on the Front Line", https://oem.bmj.com/content/oemed/77/5/281.full.pdf, accessed on May 2020.

103 International Labour Organisation, “COVID-19: Are There Enough Health Workers?", https://ilostat.ilo.org/2020/04/03/covid-19-are-there-enough-health-workers/, accessed on May 2020.

104 lbid.

105 Nursing Personnel Convention 1977 (No. 149), article 7.

106 Occupational Safety and Health Convention 1981 (No. 155), article 16.

$107 \mathrm{lbid}$, articles 16(3) and 21.

108 Ibid, article 16.

109 Ibid, article 19(e).

$110 \quad$ Ibid, article 18.

111 Article 14 Labour Inspection Convention 1947 (No. 81) jo. Protocol of 2002 to the Occupational Safety and Health Convention, 1981 (No. P155), article 4.

112 Occupational Safety and Health Convention, 1981 (No. 155), article 19(f).

$113 \mathrm{Ibid}$, articles 13 and 19(f). 
There are divergent views on the classification of COVID-19 as an occupational disease. There appears to be a regulatory gap regarding diseases caused by biological hazards. It is trite that the main goal of occupational safety and health policy is to reduce the occurrence of workplace hazards aimed at preventing workrelated accidents and injury to health. ${ }^{114}$ The International Labour Organisation has opined that COVID-19 can be regarded as an occupational disease if it is contracted through occupational exposure. ${ }^{115}$ This is more so that the infectious and viral nature of COVID-19 renders it a biological agent that poses a risk to the health of workers. As such, a worker who becomes incapacitated as a result of the pandemic should be entitled to cash compensation and medical and allied care. ${ }^{116}$ As long as the incapacitation occurred at the workplace, there is a need to compensate workers infected by COVID-19 through paid sick leave or sickness benefit to compensate for the loss of earnings. ${ }^{117}$ Cash incentives should be paid to a worker whose salary has been suspended and is absent from work due to quarantine or preventive or curative medical care. ${ }^{118}$ It is important to consider the peculiar needs of the workforce, which may include but are not limited to those arising from family responsibilities which should guide the making of shift-work arrangements and assignments to night work. ${ }^{119}$ Also, help should be provided for workers who have sick family members to care for. ${ }^{120}$ Where risks are unavoidable, measures need to be put in place to reduce the occurrence of such risks. The measures may include the provision and use of protective clothing, shorter working hours, more frequent rest breaks, temporal removal from the risk, and financial compensation in the event of exposure. ${ }^{121}$ Where death results from the contraction of the disease in the course of work, the dependants of the deceased worker (spouses and children), the employer has an obligation to provide the dependant's cash benefits or compensation, and funeral grant. ${ }^{122}$ To some extent, these international labour standards have been incorporated by domestic labour standards.

Under section 17(3) (c) Constitution of the Federal Republic of Nigeria, 1999 (as amended), the government is obliged to direct its policy towards ensuring that the health, safety, and welfare of all persons in employment are safeguarded and not endangered. Without prejudice to the non-justiciability of this provision for falling within the ambit of the Fundamental Objectives and Directive Principles of State

\footnotetext{
Ibid, article 4(2).

Annex of the List of Occupational Diseases Recommendation, 2002 (No. 194), paragraph 1.3.9.

The Employment Injury Benefits Convention 1964 (No. 121).

Social Security (Minimum Standards) Convention, 1952 (No. 102), Part III.

Medical Care and Sickness Benefits Recommendation 1969 (No. 134), paragraph 8.

Workers with Family Responsibilities Recommendation 1981 (No. 165), paragraph 19.

Medical Care and Sickness Benefits Recommendation 1969 (No. 134), paragraph 10.

Nursing Personnel Recommendation 1977 (No. 157), paragraph 49.

122 Employment Injury Benefits Convention, 1964 (No. 121), Articles 6, 8, 9, 10 and 18 jo. List of Occupational Diseases Recommendation 2002 (No. 194), paragraph 2.1.12 and 2.4.1.
} 
Policy, ${ }^{123}$ this constitutional prescription strengthens the entrenchment of occupational safety and health in labour policies and regulations. It also gives impetus to section 49 of the Factories Act 2004, which empowers the Honourable Minister of Labour and Productivity to make regulations for the purpose of securing the safety, health, and welfare of workers in workplaces. It is obligatory for employers to provide free personal protective equipment to the workers. ${ }^{124}$ Personal protective equipment includes suitable protective clothing, gloves, footwear, goggles, and head coverings. ${ }^{125}$ The additional obligation regarding the provision of adequate medical and health facilities for all persons (inclusive of health and other workers) ${ }^{126}$ aligns with a similar obligation imposed under international labour standards. ${ }^{127}$ Even in the absence of domestication as prescribed by the constitution, ${ }^{128}$ non-domestication of international labour standards pose no enforcement threat. The National Industrial Court of Nigeria is empowered to apply ratified and undomesticated international labour standards and regulations. ${ }^{129}$ This includes and applies to the Occupational Safety and Health Convention, 1981 (No. 155) 130 and the Underground Work (Women) Convention, 1935 (No. 45) ${ }^{131}$, which both represent a global consensus on the need to create a healthy and safe work environment. The employer has the duty to ensure that adequate care and safety measures exist at the workplace and not unnecessarily expose the employees to workplace-associated risk once the employer-employee relationship subsists. ${ }^{132}$ However, at the domestic level in Nigeria, enforcement of occupational safety and health is evidently poor as the Inspectorate Division of the Federal Ministry of Labour and Productivity in Nigeria has been ineffective. ${ }^{133}$

It is imperative to note that some workers do not benefit from these protective measures despite the utility of these provisions. Also, workers in the informal sector are more susceptible to workplace health and safety risks because they are excluded from the scope of protection. This position can only be remedied by appropriate reforms. At any rate, the workplace can be re-opened, even in the face

123 Constitution of the Federal Republic of Nigeria 1999 (as amended), section 6(6)(c); Attorney General of Ondo State v. Attorney General of the Federation \& Ors (2002) LPELR-623 (SC) 46, paragraph C-D; Archbishop Anthony Okogie v. Attorney General of Lagos State (1981) 2 NCLR 337 at 350. A legislation or any part of it is said to be non-justiciable when it cannot be positively enforced by courts within a particular jurisdiction.

124 Factories Act 2004, section 47.

$125 \mathrm{Ibid}$, sections 47 and 48.

126 Constitution of the Federal Republic of Nigeria 1999 (as amended), section 17(3)(d).

127 Nursing Personnel Convention 1977 (No. 149), article 7.

128 Constitution of the Federal Republic of Nigeria 1999 (as amended), section 12(1).

129 Ibid, section 254(C)(2) jo. 7(6) National Industrial Court Act 2006.

130 The Occupational Safety and Health Convention 1981 (No. 155) was ratified on $3^{\text {rd }}$ May 1994.

131 The Underground Work (Women) Convention 1935 (No. 45) was ratified on $17^{\text {th }}$ October 1960.

132 lyere v. Bendel Feed \& Flour Mills Ltd. (2008) 18 NWLR (Pt 119) 300.

133 EE Idubor and MD Oisamoje, "An Exploration of Health and Safety Management Issues in Nigeria's Effort to Industrialize", European Scientific Journal, Vol. 9, No. 12, 2013, p. 12. 
of the threats posed by COVID-19, so long as strict occupational safety and health criteria aimed at minimising the risk to workers of exposure are met. Safe and healthy workplace conditions are germane for vibrant policy guidance upon which return to work is based. ${ }^{134}$ The formulation of the policy should be given a humancentered approach that puts rights and international labour standards at the heart of economic, social, and environmental strategies. It also ensures that policy guidance is embedded in national occupational safety and health systems. ${ }^{135} \mathrm{~A}$ detailed risk assessment should be the deciding factor in making the decision to open, close and reopen workplaces and to suspend or reduce work activities. ${ }^{136}$

\section{Conclusion}

It has been shown that the workplace at both domestic and international echelons has been adversely affected by the outbreak of COVID-19 in an unprecedented manner. The pandemic imposed diverse impacts on employers of labour, employees of various divides, trade unions, and governments across the globe. It is also established that there is a need for a collective role on the part of the government, workers, and employers to ameliorate the adverse effect of the pandemic in the workplace. As such, all stakeholders in the workplace must continue to evolve effective strategies to mitigate the socio-economic impact of the pandemic on the workplace. In this regard, workplace mechanisms for activating collective bargaining as well as an institutional mechanism for enforceability of outcomes (inclusive of collective agreements) should be enhanced. Protective and remedial legal norms should be transient, flexible, and proactive to accommodate diverse situations as well as changing work patterns capable of undermining the prospects of labour laws, regulations and policies. Appropriate flexible working arrangements, tax rebates/deferral, and financial stimulus remain options open for adoption. Protective practices relating to the use of face masks, regular and routine cleaning and disinfecting of surfaces, desks, doors, and other work tools and equipment should be done. This should be capped with access to essential health care and other basic social services in the workplace. There must be a proactive legislative response that ensures that workers and the workplace get the needed support, and such provisions are couched in a manner that guarantees both de jure and de facto protection.

\section{References}

\section{Books}

\footnotetext{
134 International Labour Organisation, "A Safe and Healthy Return to Work During The COVID-19 Pandemic" https://www.ilo.org/global/topics/safety-and-health-at-work/resourceslibrary/publications/WCMS_745549/lang--en/index.htm, accessed on May 2020.

135 Ibid, p. 2.

136 Ibid, p. 5.
} 
Agomo, Chioma Kanu, Nigerian Employment and Labour Relations: Law and Practice, Concept Publications Limited, Nigeria, 2011.

Baldwi, Richard, and Beatrice Weder di Mauro, Economics in the Time of COVID-19, Centre for Economic Policy Research, United Kingdom, 2020.

Emiola, Akintunde, Nigerian Labour Law, Emiola Publishers Limited, Nigeria, 2008.

Evci, Samet, and Anshuman Sharma, Studies at the Crossroads of Management \& Economics, ljopec Publication, Turkey, 2020.

Fashoyin, Tayo, Industrial Relations in Nigeria: Development and Practice, Learn Africa Plc, Nigeria, 1992

Nwagbara, Determination of Contract of Employment and Remedies for Wrongful Dismissal, Tait Publishers, Nigeria, 2000.

Ogunniyi, Oladosu, Nigerian Labour and Employment Law in Perspective, Folio Publishers Limited, Nigeria, 2004.

Oji, Elizabeth A., and Offornze D. Amucheazi, Employment \& Labour Law in Nigeria, Lawscope Publishers, Nigeria, 2019.

Otobo, Dafe, Industrial Relations: Theory and Controversies, Malthouse Press Limited, Nigeria, 2013

Srivastava, SC, Industrial Relations and Labour Law, Vikas Publishing House PVT Ltd, India, 2007.

\section{Other Documents}

Idubor, EE and MD Oisamoje, "An Exploration of Health and Safety Management Issues in Nigeria's Effort to Industrialize", European Scientific Journal, Vol. 9, No. 12, 2013.

International Labour Organisation, "A Safe and Healthy Return to Work During The COVID-19 Pandemic" https://www.ilo.org/global/topics/safety-and-health-atwork/resources-library/publications/WCMS_745549/lang--en/index.htm.

"COVID-19: Are There Enough Health Workers?", https://ilostat.ilo.org/2020/04/03/covid-19-are-there-enoughhealth-workers/.

Workplace",

"COVID-19: Protecting Workers in the ilo/newsroom/news/WCMS_740101/lang--en/index.htm.

"ILO Monitor: COVID-19 and the World of Work", https://www.ilo.org/global/topics/coronavirus/impacts-andresponses/WCMS_767028/lang--en/index.htm.

"ILO: As Job Losses Escalate, Nearly Half of Global Workforce at Risk of Losing Livelihoods", https://www.ilo.org/global/about-theilo/newsroom/news/WCMS_743036/lang--en/index.htm. 
"International Labour Standards on Employment Security", http://www.ilo.ch/global/standards/subjects-coveredby-international-labour-standards/employment-security/lang--en/index.htm.

"Labour Force",

https://www.ilo.org/global/statistics-and-databases/statistics-overview-andtopics/WCMS_470304/lang--en/index.htm.

, "World Employment and Social Outlook: Trends 2020", https://www.ilo.org/wcmsp5/groups/public/---dgreports/---dcomm/--publ/documents/publication/wcms_734455.pdf.

"ILO Standards and COVID-19 (Coronavirus)", https://www.ilo.org/wcmsp5/groups/public/---ed_norm/--normes/documents/publication/wcms_739937.pdf.

International Monetary Fund, "IMF Country Focus: Nigeria's IMF Financial Assistance to Support Health Care Sector, Protect Jobs and Businesses", https://www.imf.org/en/News/Articles/2020/04/29/na042920-nigerias-imffinancial-assistance-to-support-health-care-sector-protect.

Moreno, Juan Pablo López, Luz Angela Duarte González and Juliana Morad, "COVID19 and Labour Law: Colombia", Italian Labour e-Journal, Vol. 13, No. 1S, 2020.

National Bureau of Statistics, "Labour Force Statistics - Volume I: Unemployment and Underemployment Report (Q4 2017-Q3 2018)", https://nigerianstat.gov.ng/.

National Bureau of Statistics, "Labour Force Statistics: Unemployment and Underemployment Report (Q4 2020)", https://nigerianstat.gov.ng/.

Obidimma, Emmanuel OC, MI Anushiem and UMJ Ekeneme, "Unfair Dismissal in Nigeria: Imperative for A Departure from The Common Law", Nnamdi Azikiwe University Journal of International Law and Jurisprudence, Vol. 7, 2016.

Odiase, Philip Osarobo, "COVID-19 and Labour Law: Nigeria", Italian Labour Law eJournal, Vol. 13, No. 1S, 2020.

Oliver, Will, "Healthcare Workers and Coronavirus: Behind the Stiff Upper Lip We Are Highly Vulnerable", https://theconversation.com/healthcare-workers-andcoronavirus-behind-the-stiff-upper-lip-we-are-highly-vulnerable-133864.

Omitogun, Olawunmi and Adedayo Emmanuel Longe, "Unemployment and Economic Growth in Nigeria in the $21^{\text {st }}$ Century: VAR Approach", Acta Universitatis Danubius, Vol. 13, No. 5, 2017.

Sim, Malcolm R, "The COVID-19 Pandemic: Major Risks to Healthcare and Other Workers on the Front Line", https://oem.bmj.com/content/oemed/77/5/281.full.pdf.

United Nations, "Nearly Half of Global Workforce at Risk as Job Losses Increase Due to COVID-19: UN Labour Agency", https://news.un.org/en/story/2020/04/1062792. 
University of Oxford, "Oxford COVID-19 Vaccine to Begin Phase II/III Human Trials", http://www.ox.ac.uk/news/2020-05-22-oxford-covid-19-vaccine-begin-phaseiiiii-human-trials.

World Health Organization, "WHO Coronavirus Disease (COVID-19) Dashboard", https://covid19.who.int/.

\section{Legal Documents}

The Constitution of the Federal Republic of Nigeria 1999.

The Employment Injury Benefits Convention 1964 (No. 121).

The Employment Promotion and Protection Against Unemployment Convention 1988 (No. 168).

The Labour Inspection Convention 1947 (No. 81).

The Nursing Personnel Convention 1977 (No. 149).

The Occupational Safety and Health Convention 1981 (No. 155).

The Occupational Safety and Health Convention 1981 (No. 155).

The Protection of Wages Convention 1949 (No. 95).

The Protocol of 2002 to the Occupational Safety and Health Convention, 1981 (No. P155).

The Social Security (Minimum Standards) Convention 1952 (No. 102).

The Termination of Employment Convention 1982 (No. 158).

The Underground Work (Women) Convention 1935 (No. 45).

The Workers with Family Responsibilities Convention 1981 (No. 156).

The Covid-19 Emergency Regulations 2020.

The Factories Act 2004.

The Labour Act 2004.

The National Minimum Wage (Amendment) Act 2011.

The Quarantine Act 1926 is currently codified as Cap Q2, Laws of the Federation of Nigeria 2004.

Annex of the List of Occupational Diseases Recommendation, 2002 (No. 194).

List of Occupational Diseases Recommendation 2002 (No. 194)

Medical Care and Sickness Benefits Recommendation 1969 (No. 134).

The Employment Promotion and Protection against Unemployment Recommendation 1988 (No. 176).

The Termination of Employment Recommendation 1982 (No. 166).

Archbishop Anthony Okogie v Attorney General of Lagos State (1981) 2 NCLR 337.

Attorney General of Ondo State v. Attorney General of the Federation \& Ors (2002) LPELR-623 (SC)

Ebere Onyekachi Aloysius v. Diamond Bank Plc (2015) 58 NLLR (Pt 199) 92.

Food, Beverage \& Tobacco SSA v. Premier Breweries (1989-90) NICLR 56.

Gabriel Ativie v. Kabel Metal Nig. Limited (2008) LCN/3539 (SC). 
Isievwore v. NEPA (2002) 13 NWLR (Pt 784) 417, 434.

lyere v. Bendel Feed \& Flour Mills Ltd. (2008) 18 NWLR (Pt 119) 300.

Nigerian Oil Mills Ltd. v. Daura (1996) 8 NWLR (Pt 468) 601.

Olaniyan v. University of Lagos \& Anor (1985) 2 NWLR (Pt 9) 599, 612.

Petroleum and Natural Gas Senior Staff Association of Nigeria v. Schlumberger Anadrill Nigeria Ltd. (2008) 11 NLLR (Pt 29) 164.

Union of Shipping, Clearing and Forwarding Agencies Workers of Nigeria v. Management of Transatlantic Nigeria Limited (1988) Unreported Suit No. NIC/14/87. 